\title{
POLITICAL CORRUPTION AS EROSION OF THE RIGHT AND THE
} PRAYER

\author{
Biljana Paneva Parleeva \\ MPhil in second cycle of legal studies (judicial direction) at Goce Delcev University, \\ Stip, Republic of Macedonia \\ bpanevaparleeva@yahoo.com
}

\section{Professional Paper doi:10.5937/jouproman6-17464}

\begin{abstract}
In the last 20 years despite the discovery of the ever-increasing factors of political corruption, as well as the "everyday seemingly" tackling of political corruption and the preventive actions of state institutions, our country cannot boast some significant changes in this field: old problems have not yet been resolved, and existing problems prevail daily. Many political actors in the country, that is, those politicians who have "welled up" with oppressive political incursions in order to grab their own benefit or for the benefit of the political party they represent, would secretly say that it is good that there is corruption, "Lubricates" the business in conditions when it cannot run in a fast, regular way. The scientific paper analyzes the negative impact of this phenomenon in our country, as well as its negative consequences on the rule of law, the destruction of the human individual and morality, the destruction of the market economy, free competition, and so on.
\end{abstract}

Key words: political corruption, political parties, state institutions, executive power.

\section{Introduction}

Corruption prevents economic growth and creates economic hell. Even Dante Alighieri put bribe-makers at the very bottom in hell (Marjan Nikolov, 2004, p. 135 - Economic and Political Implications of Corruption in the Republic of Macedonia, Center for Economic Analysis). Corruption is a global world phenomenon, an impending evil that every country must take seriously. Corruption is always subjective and always crosses the boundaries of law and morality. Corruption threatens the political stability of the state, the trust of citizens in the political and judicial system, the rule of law, economic development, foreign investment and European integration. Corruption reduces the trust of citizens in the institutions of the system, completely violates the rule of law in the country, creates a feeling of hopelessness among the citizens, imposes a wrong and destructive system of values in the state and in the citizens, causes the politics to be hostage to the business and the criminal structures, prevents the necessary democratization of political parties, encourages and intensifies the process of brain drain and significantly reduces the possibilities for reforms and for the European integration it (Zoran Jacev, 2004, p.62, Publication of the Second Conference of Macedonia and Corruption Situation and Challenges, Foundation Open Society Institute - Macedonia). As a consequence of non-investment in the primary sources of economic growth: physical capital, human capital and social capital, and a change in the value system at the beginning of the transition, the first forms of political corruption appear. There is no doubt that in the last decade political corruption has seen such an increase that has not been observed in the last 50 years due to the change in the sociopolitical and economic system, the state regulation, the transition period, the privatization of social property and the accumulation of capital in certain private companies close to the authorities, etc. 
The insufficient efficiency of state bodies, institutions and services led to the rapid increase in political corruption in the Republic of Macedonia (Gorgi Naumov, 2004, p.22, Publication of the Second Conference Macedonia and Corruption situation and challenges, Foundation Open Society Institute - Macedonia). For a decade the Republic of Macedonia exists in an anemic state. The etiological political factor for the appearance of corruption is concentrated on unlimited executive power. The main location of corruption is the political party, which strives to come to power, not because of the grandiose political goals but for the material gains that come from the ministerial portfolios and the patronage of political parties. (Todor Vitlarov, 2006, p.364, an excerpt from the book „Repression and Prevention of Corruption").

\section{The action of political parties - a nest of political corruption}

The main location of corruption in Macedonia is the political party (Hislop, 18). More party inter-ethnic coalitions are a regular feature of Macedonia's political life after gaining independence, but those coalitions are coalitions of interest, not commitment. According to Professor Kambovski, three main patterns of behavior of political parties can be recognized. One period is for the party to "take over" a particular state institution after a particular member of that party is appointed as its director. This means that all key positions in the institution will be filled with party members. It is a routine phenomenon when it comes to state-owned enterprises. The second tendency is for party-controlled stateowned enterprises to be used as personal property of party members. In such a case, the party transfers the resources and assets of the enterprise, for the sake of its own profit and enjoyment. Such a fate had: Macedonia Tobacco, Electric Power Company of Macedonia, Health Fund, etc. The third tendency is some kind of nepotism, that is, the filling of the state administration with unskilled party cadres, party soldiers and influential friends were appointed as deputies and assistant ministers, directors, undersecretaries, chiefs, etc. (Kambovski, 2, 26). By this way of appointing directors or responsible persons in public enterprises, the legal institute for public announcement is actually suspended - a competition for appointing directors or responsible persons in public enterprises. When a particular party comes to power, with a decision of the appropriate minister, in all public enterprises under its jurisdiction, party people are appointed for acting directors. Such is the situation in medical centers, schools, branches of Electric Power Company, Customs, Public Utilities. In 2001, after a series of acquired properties by one of the then political parties in power, the Constitutional Court of the Republic of Macedonia in 2001 abolished the provision from the Law on Financing of Political Parties, which allowed such property ("Official Gazette of the Republic of Macedonia" Macedonia "No.70/01).

Political parties do not receive money because firms believe in their political platforms and programs or because politicians are sympathetic to business customers. Our businessmen or financiers understand this as a good investment that needs to be returned to them with profit, and sometimes even with extra profit (excerpt from Utrinski vesnik, August 22, 2002, an interview with the President of Transparency).

\section{Political corruption in the conduct of elections}

The only way for the financiers to repay the invested millions of euros in the election campaign is to put politicians and political parties in a more favorable situation when paying their obligations to the state, taxes or customs, or to put them in a privileged position in the privatization or public procurements process. In the pre-election there are various party activists, who are very indebted to the parties, they work on the field, engage people and lobby voters, and expect them to discharge after the elections, or at best expect to be placed in power at the national or local level. 
There are local powermen who, immediately after the elections, receive their promised privileged positions and privileges. Also, by party activists, there is an open bribing of potential voters (usually poorer and uneducated citizens) who, instead of being led by their free will, are tempted to accept the enticing offer, thus turning the elections into trade deals between citizens and candidates on election lists.

\section{Infiltration of political corruption in state institutions and executive power}

Media - Journalism as the pillar of democracy is losing the battle with political corruption imposed by political and economic power centers. The media market has been turned into a gladiatorial arena in which the rules either do not exist or are ignored. All the anomalies are most evident at the time of the elections, when the media donate advertising time to the political parties, which is a serious legal anomaly that needs to be changed immediately. If, on the one hand, the government favors certain media through a policy of advertising with budget funds, there is a situation where some of the same private businesses advertise constantly and only on one medium or in the same broadcast. The circulations are hidden as if they were a military secret, and the ratings of the broadcasters for years have been subject to distrust both by the market participants and the expert public. (statement by Biljana Petkovska, director of the Macedonian Institute for Media, an excerpt from Dnevnik 20. 02. 2012).

Police - Party personnel shifts occur in the police. High professional functions are taken by people from side, who are not only without proper education, but also without any previous experience. All these conditions reflect the professionalism of the police, in general in the fight against criminality. There is always political repatriation by the ruling party towards the political party that was previously in power, and now it is the opposition that can be seen most from the subjects against which criminal charges are filed, and it has a high level of selectivity. Prisoners who have committed a crime of murder over political agreements between coalition partners are released. A police hike is conducted and members of the previous government are detained for acts for which there is no evidence, or the evidence is bent and incomplete or incomplete, and the presumption of innocence is violently and irresponsibly violated. Brutally handled falsely charged detainees, which is a work of political retaliation for which there are no borders.

The Public Prosecutor's Office - The Public Prosecutor's Office is the only state independent body that prosecutes perpetrators of criminal acts, but it is proposed by the government, and the mandate is limited, and it is not ensured independence in the performance of its function. With the new Law on Public Prosecution, one step forward was made regarding the issue of autonomy in the public prosecutor's office and a permanent mandate was introduced for the deputies of the public prosecutor.

The nomination of candidates for public prosecutors and deputies remains the responsibility of the executive power - the government. There are cases of prolongation of the procedures for the adoption of an appropriate public prosecutor's decision when it comes to registered persons from the current headquarters or close relatives. Or, in order to get in time, an application for collecting prior notices from authorities and in a manner, which they themselves know will not receive, is submitted upon application.

Judiciary - The Judiciary demonstrates promptness in resolving cases, except for the crime of Abuse of official position and authority. The judiciary is not free from subjectivism, and there are a large number of cases in which the investigation lasts for long, or the main searches are unnecessarily postponed. 
The manner of functioning of the state administration - the constant party "airing" of the state administration, contributed to the employment of non-professional persons party staff, which have a direct impact on the efficient exercise of the rights of the citizens and the occurrence of various cases of connections or bribes and giving a bow to get a certificate or certificate.

Authorities - A problem with us is the nonfunctioning of the government bodies on the whole territory of the country. There are parts of our country where taxes are not collected, where utilities are not paid, where the state officials - the police officers are most openly attacking. In a large number of proceedings against members of another nationality, attempts are made to give them political connotation, not the criminal one they deserve.

There are pressures on official bodies that carry out the criminal procedure to deviate from legal solutions due to some kind of relaxation of inter-national relations (Todor Vitlarov, 2006, p.296 - excerpt from the book „Repression and prevention of corruption“").

\section{Prevention of political corruption}

When it comes to the prevention of corruption and conflicts of interest, it is necessary to create a political culture and value system in which corruption will be clearly identified as a social evil that should be constantly prevented and sanctioned. In addition to the institutions responsible for the fight against corruption and conflicts of interest, a particularly important role is played by the non-governmental sector, which with its mechanisms of action is a significant entity in the fight against these social evils. In the battle against corruption, the circumstances that contribute to the appearance of crime and corruption in the state must be resolved. According to Professor Todor Vitlarov, a new incrimination should be prescribed for resolving this problem: Abuse in the performance of the duties of state power. Such incrimination will also mean punitive legal sanctioning of the conflict of interests and resolving the issue of conflict between personal and social interest. Due to the past experience with the method of financing political parties, the use of budget funds for party goals, as well as the overflow of funds from the funds of public enterprises for party purposes, we consider that a new incrimination should be prescribed, which will sanction such phenomena, and such as: misuse of budget funds and funds from public funds, as well as non-fulfillment of the legal obligation to report property and change of assets. Also in the direction of greater prevention, in a general and special plan, as well as taking a concrete step in the penal and legal sense, in order to overcome the situation in the judiciary, we consider that it is necessary to prescribe a special incrimination: Receiving a bribe by a judge, as well as Receiving and giving bribes in trade transactions for the prevention of corruption in the private sector (Todor Vitlarov, 2006, p.288 - excerpt from the book "Repression and prevention of corruption"). One has to work in the field of democratization of the entire society, and in this direction the political executive power, as prescribed by the Constitution, must be responsible for its work in front of the Parliament, as the highest authority of the government. The estimates for the work of certain ministers should be based on facts and shown positive results in the performance of their function. All corruption affairs should be disclosed and clear political signals to the competent authorities, to take all legal actions, regardless of who it is and what position it currently occupies in the country. The police should be free of all party pressures, guided by its basic function for detecting perpetrators of criminal acts, within its legal competences. The public prosecutor's office must be completely separated from the political-executive power - the government and must be relieved of any estimates of prospects in criminal prosecution, and the principle of legality must be respected consistently. 


\section{Conclusion}

Specific measures and concrete actions are needed, the reasons that lead to political corruption and the creation of material, staffing and other conditions for the work of the institutions should be removed. New more comprehensive penal legal norms should be created for incriminating the corruption actions, which we discussed at point 5 . Prevention of political corruption. The existing penal legal norms should be consistently applied by the state authorities in which the competence includes the detection, prosecution and adjudication of corruption offenses. It is necessary for the state institutions to employ the appropriate merit system and not according to the spill system, employing unskilled personnel, and quality personnel who do not have connections in foreign countries. It is necessary to implement all the most favorable international instruments and to make them alive in the Macedonian legislation, giving a sense of security among the citizens that political corruption is not worthwhile and extremely immoral, which as a kind of erosion of law and morality has far negative consequences.

I have the impression that in the Republic of Macedonia in the fight against corruption only rush the surface. And if you get a bit deeper, you risk getting burned or cut off your arm. Of course I say this metaphorically, and I know exactly what I mean, because the battle against corruption and crime does not involve belonging to any political structure, because crime is a crime, regardless of who did it and how. And of course, there must be a court order, to be an example for others who are deeply penetrated into the mud, called corruption (a statement by Mihailo Manevski, Ibid).

\section{Literature}

1. Marjan Nikolov, 2004, p. 135 - Economic and Political Implications of Corruption in the Republic of Macedonia, Center for Economic Analysis,

2. Zoran Jacev, 2004, p.62 - Publication of the Second Conference Macedonia and Corruption Situation and Challenges, Foundation Open Society Institute - Macedonia,

3. Gorgi Naumov, 2004, p.22 - Publication from the Second Conference Macedonia and Corruption Situation and Challenges, Foundation Open Society Institute - Macedonia,

4. Todor Vitlarov, 2006, str.364 - an excerpt from the book "Repression and Prevention of Corruption s"

5. Hislop, 18

6. Kambovski, 2, 26

7. Official Gazette of the Republic of Macedonia (No.70/01)

8. Excerpt from Utrinski vesnik, 22.08.2002, interview with the President of Transparency

9. Statement by Biljana Petkovska, director of the Macedonian Institute for Media, an excerpt from Dnevnik 20. 02. 2012

10. Todor Vitlarov, 2006, p.296 - excerpt from the book "Corruption Repression and Prevention"

11. Todor Vitlarov, 2006 , p.288 - excerpt from the book "Corruption Repression and Prevention"

12. Statement by Mihailo Manevski (Ibid). 